\title{
Occurrence of Cymbasoma longispinosum Bourne, 1890 (Copepoda: Monstrilloida) in the Curuçá River estuary (Amazon Littoral)
}

\author{
NATÁLIA R. LEITE ${ }^{1}$, LUCI C.C. PEREIRA ${ }^{2}$, FERNANDO ABRUNHOSA ${ }^{3}$, \\ MARCUS A.B. PIRES ${ }^{3}$ and RAUQUíRIO M. DA COSTA ${ }^{1}$ \\ ${ }^{1}$ Laboratório de Plâncton e Cultivo de Microalgas, Instituto de Estudos Costeiros (IECOS), \\ UFPA, Campus Universitário de Bragança, Alameda Leandro Ribeiro s/n, Aldeia \\ 68600-000 Bragança, PA, Brasil \\ ${ }^{2}$ Laboratório de Oceanografia Costeira e Estuarina, Instituto de Estudos Costeiros (IECOS), \\ UFPA, Campus Universitário de Bragança, Alameda Leandro Ribeiro s/n, Aldeia \\ 68600-000 Bragança, PA, Brasil \\ ${ }^{3}$ Laboratório de Carcinologia, Instituto de Estudos Costeiros (IECOS), \\ UFPA, Campus Universitário de Bragança, Alameda Leandro Ribeiro s/n, Aldeia \\ 68600-000 Bragança, PA, Brasil
}

Manuscript received on April 3, 2009; accepted for publication on June 17, 2009

\begin{abstract}
The present work was carried out to verify the occurrence and distribution of Cymbasoma longispinosum Bourne, 1890 in a tropical Amazon estuary from North Brazil. Samplings were performed bimonthly from July/2003 to July/2004 at two different transects (Muriá and Curuçá rivers) situated along the Curuçá estuary (Pará, North Brazil). Samples were collected during neap tides via gentle (1 to 1.5 knots) $200 \mu \mathrm{m}$-mesh net tows from a small boat. Additional subsurface water samples were collected for the determination of environmental parameters. Males and females of Cymbasoma longispinosum were only observed during September and November/2003. The highest number of organisms was found in September/2003 at the Muriá River transect. The presence of C. longispinosum in samples obtained during September and November/2003 could probably be related to the reproductive period of this species in the studied estuary, which is directly related to the dry period in the region. The highest salinity values and the highest number of individuals observed in September/2003 corroborate with the previous assumption, since no C. longispinosum was found during the months comprising the rainy period (January to June).
\end{abstract}

Key words: Amazon region, Monstrilloida, new occurrence, tropical estuary.

\section{INTRODUCTION}

Monstrilloida constitutes the least known copepod order. Its biology and ecology are poorly known, completely differing from all other Copepoda (Calanoida, Cyclopoida, Harpacticoida, Poecilostomatoida and others) in their peculiar life cycle (Dias 1996). Individuals of this order present most of their naupliar and post-naupliar stages as parasites of benthic invertebrates, mainly poly-

Correspondence to: Prof. Dr. Rauquírio Marinho da Costa E-mail: raucosta@ufpa.br chaetes and molluscs (Suárez-Morales and Gasca 1998). The first naupliar and adult planktonic free-swimming stages do not present specialized mouth appendices (Huys and Boxshall 1991).

Free-living, planktonic, non-feeding adults emerge from their hosts and remain in the water column during the reproductive period (Davis 1984), making them relatively rare in plankton samples (Dias 1996), with dependence on nutritive reserves accumulated within the body-cavity during their juvenile existence (Davis 1984, 
Dias 1996, Suárez-Morales and Gasca 1998). After the first naupliar stage, these organisms experience a gradual transformation inside their host body assuming the definitive appearance of adult copepods (Dias 1996). The presence of a mouth located on an oral papilla linked to a small pharynx and situated, generally, in the center of the cephalic segment is one of the peculiar characteristics for organisms within this order (Davis 1984, Dias 1996).

The purpose of this study, part of the "Milênio Project" (Use and Appropriation of Coastal Zone Resources - RECOS), was to notify the first occurrence of Cymbasoma longispinosum Bourne, 1890 (Copepoda, Monstrilloida), as well as to describe some aspects of its population dynamics, such as density and spatial and temporal distribution in the Curuçá estuary (Pará State Amazon region, North Brazil).

\section{MATERIALS AND METHODS}

\section{STUdy AREA}

The Northeast littoral of Pará State extends from the mouth of the Pará River to the mouth of Gurupi River, an extension of $600 \mathrm{~km}$ (Souza Filho and El-Robrini 1997). The geographic position of Northeast Pará's coast $\left(0-1^{\circ} \mathrm{S}\right)$, together with the coastal embayment and the great width of the Pará/Maranhão continental shelf, propitiates the development of a high energy environment dominated by semidiurnal macrotides with heights ranging from 4 to $6 \mathrm{~m}$ (DHN 2007).

The Atlantic "Paraense" salt coast is represented by long bays with depths oscillating from 5 to $15 \mathrm{~m}$ and extensions around $20 \mathrm{~km}$ (El-Robrini 1992). The rivers wide mouths present creek channel characteristics and are submitted to coastal marine influences that can be observed up to $45 \mathrm{~km}$ inland. In these conditions, mud plains are formed and become mainly colonized by mangrove forests (Mácola and El-Robrini 2004).

According to Prost and El-Robrini (1997), the Northeast "Paraense" coast is located in the center of a large tropical atmospheric circulation system that, together with the Amazon River hydric and sediment water discharges, exerts a strong influence on the actual coastal dynamics.

Curuçá County $\left(00^{\circ} 43^{\prime} 48^{\prime \prime} \mathrm{S}\right.$ and $\left.47^{\circ} 51^{\prime} 06^{\prime \prime} \mathrm{W}\right)$ is located in the micro region of "Salgado", in the middle of Northeast Pará, with an area of approximately $673 \mathrm{~km}^{2}$. It is limited to the North by the Atlantic Ocean, to the South by Terra Alta County, to the East by Marapanim County and to the West by São Caetano de Odivelas County.

The region's climate is Amazon equatorial according to Köppen classification criteria, and it is characterized by high temperatures with an average value of $27^{\circ} \mathrm{C}$, a small thermal amplitude and abundant rainfall regimen that surpasses 2000 mm.year ${ }^{-1}$, with the months of January to June comprising the rainy period and July to December the dry period.

The studied area presents tide heights of $4 \mathrm{~m}$, with higher values $(5.5 \mathrm{~m})$ observed during equinoctial spring tides. Salinity in this region ranges from 20 to 22 during the rainy season, and 30 to 35 in the dry season. Vegetation along the margins of the Curuçá estuary is characterized by mangrove forests in which Rhizophora, Avicennia and Laguncularia are the main genera represented.

\section{ZOOPLANKTON COLLECTION AND ANALYSIS}

Zooplankton samples were collected bimonthly from July/2003 to July/2004 by means of a 3-minute horizontal plankton hauls accomplished with a $200 \mu \mathrm{m}$ mesh size plankton net, $2 \mathrm{~m}$ long and with a $0.60 \mathrm{~m}$ mouth diameter equipped with a mechanical flowmeter (Hydrobios-Kiel, Model 438 110) to estimate filtered water volume.

Samples were taken in the Muriá Creek, located along the margins of Abade village, and in the Curuçá River, which is located in the vicinity of Curuçá County. Each sampling area was comprised by 4 stations: M1, M2 M3 and M4, and C1, C2, C3 and C4, respectively (Fig. 1). Single diurnal hauls were performed during ebb neap tides, totaling 8 samples in each expedition.

Additional in situ measurements of temperature, $\mathrm{pH}$ and salinity were taken with a multianalyser equipment (Orion 105). Water transparency was determined using a Secchi disc. In order to determine concentrations of dissolved oxygen and material in suspension, $300 \mathrm{~mL}$ of surface water were also collected and analyzed according to the Winkler volumetric method (Strickland and Parsons 1972, Grasshoff et al. 1983) and the gravi- 


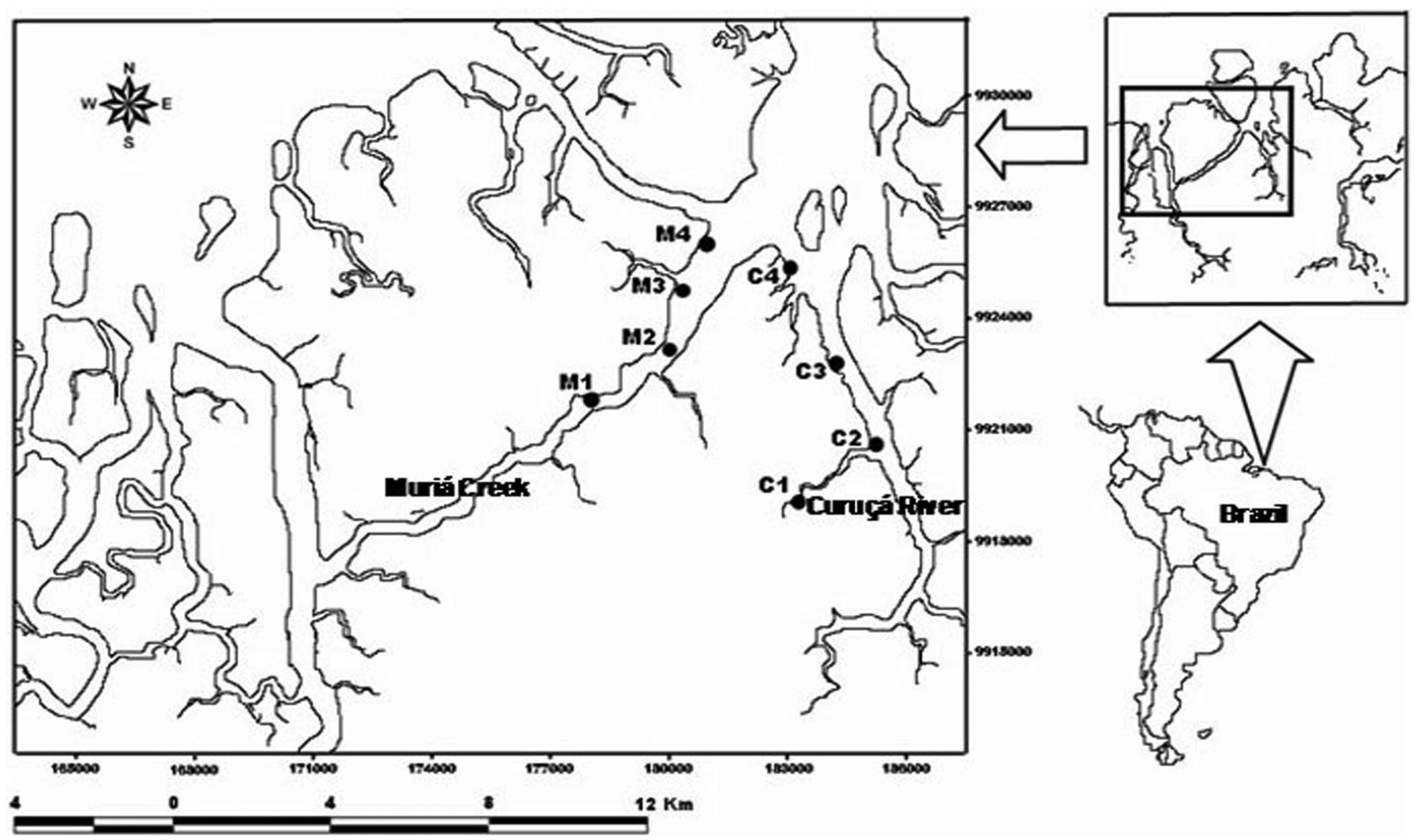

Fig. 1 - Map of Curuçá County (Amazon Region) showing the sampling stations in the Muriá Creek (M1 to M4) and Curuçá River (C1 to C4).

metric methodology adapted from Strickland and Parsons (1972).

After collection, samples were conditioned in $500 \mathrm{~mL}$ plastic flasks containing buffered formalin solution (sodium tetraborate) at 4\%. Density was determined calculating the number of sample individuals divided by the filtered seawater volume.

Collected organisms were sorted and identified using a Zeiss stereoscopic microscope (Stemi 2000), a light Zeiss microscope (Axioskop 40) and specialized literature (Rose 1933, Trégouboff and Rose 1957). Males and females were identified, dissected and illustrated through schematic drawings for a better species identification.

Total body length measurements (abdomen and cephalothorax) were taken using a micrometric scaled rule adjusted to the ocular of the microscope. The entire collection has been deposited in the Laboratory of Plankton and Microalgae Culture/Federal University of Pará-UFPA (North Brazil). Five adult females (Lot 806F) and six adult males (Lot 805-M) were deposited in the Museu Paraense Emílio Goeldi, Belém - Pará - Northern Brazil.

\section{RESULTS}

Temperature ranged from $20.6^{\circ} \mathrm{C}$ in January/2004 at the station $\mathrm{M} 1$ to $31^{\circ} \mathrm{C}$ in July/2003 at stations $\mathrm{C} 1$ and $\mathrm{C} 2$. Salinity showed a minimum value of 6.1 at station $\mathrm{C} 1$ and a maximum of 40.8 at station C4 in March/04 and November/2003, respectively. Hydrogenionic potential $(\mathrm{pH})$ oscillated from $6.87(\mathrm{March} / 2004)$ at station $\mathrm{C} 1$ to 8.12 (November/2003) at station $\mathrm{C} 4$, while dissolved oxygen concentrations ranged from 3.45 at station C1 in January/2004 to 8.42 in July/2003 at station C2. Minimum and maximum water transparency and suspended particulate matter values were $0.54 \mathrm{~m}$ (May/2004) at station M1, $5.00 \mathrm{~m}$ (November/2003) at station C3, 13 mg.L $\mathrm{L}^{-1}$ (July/2003) at station C3, and $98.6 \mathrm{mg} . \mathrm{L}^{-1}$ (January/2004) at station M1, respectively.

Males and females of Cymbasoma longispinosum were registered only in samples collected in September and November/2003 (dry period). Females were always larger than males as reported for different copepod species (Mauchline 1998).

Females and males present characteristic appendices, specifically the fifth leg, which is systematically used to differentiate sexes and also to distinguish 
different copepod species (Figs. 2 and 3). In the female, the presence of two urosomal somites, with only one free somite located between the genital double somite and the caudal rami, confirms genus identification (Isaac 1975).

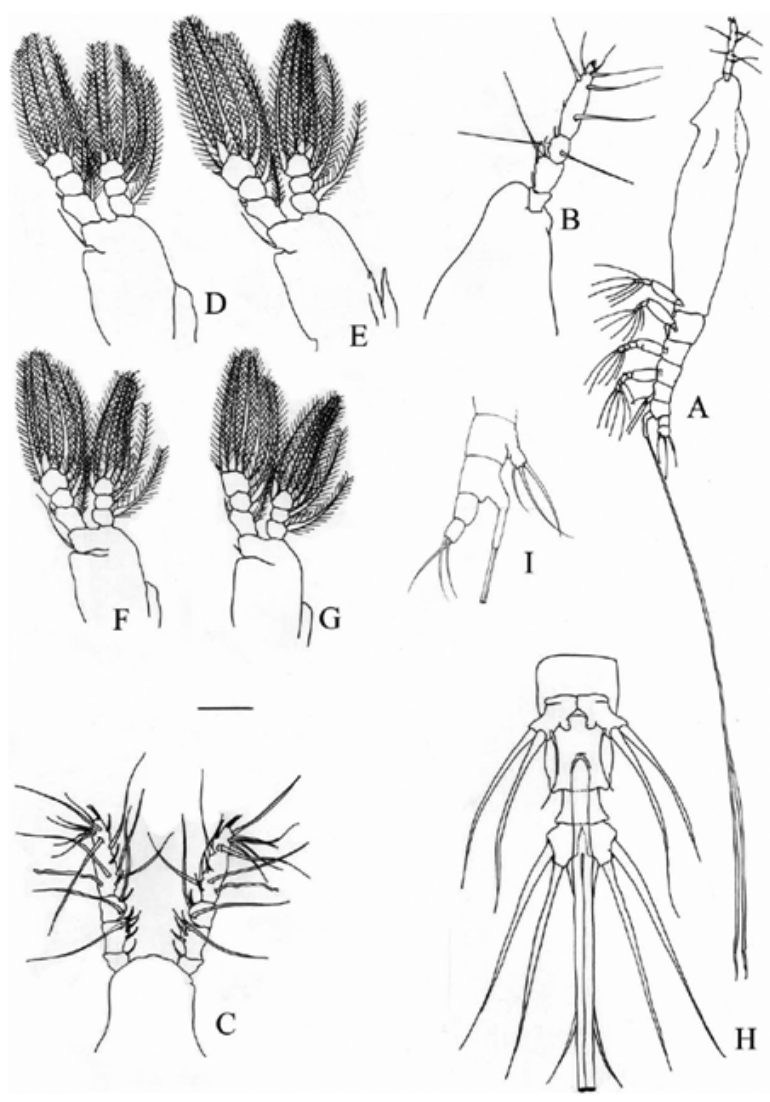

Fig. 2 - Cymbasoma longispinosum Bourne, 1890, f\#. (A) Female lateral view; (B) Lateral view of the head; (C) Dorsal view of the head; (D) Leg 1; (E) Leg 2; (F) Leg 3; (G) Leg 4; (H) Ventral view of the urosome; (I) Lateral view of the urosome. Scale bar: $\mathrm{A}=0.6 \mathrm{~mm}$; $\mathrm{B}, \mathrm{C}$ and $\mathrm{I}=0.3 \mathrm{~mm} ; \mathrm{D}, \mathrm{E}, \mathrm{F}, \mathrm{G}$ and $\mathrm{H}=0.15 \mathrm{~mm}$.

On the samples collected in September/2003, 156 individuals ( 89 males and 67 females) were observed. The Muriá sample stations showed a higher number of individuals (145) than those obtained at stations located in the Curuçá River (11). At station M1, 22 individuals comprised of 10 females and 12 males $\left(0.77\right.$ org. $\left.\mathrm{m}^{-3}\right)$ were observed. Male measured body lengths (cephalotorax and abdomen) ranged from $1.23 \mathrm{~mm}$ to $1.50 \mathrm{~mm}$ $(1.34 \pm 0.03 \mathrm{~mm}$, mean $\pm \mathrm{SD})$, while female body lengths ranged from $1.83 \mathrm{~mm}$ to $2.48 \mathrm{~mm}$, with mean values of $2.09 \pm 0.06 \mathrm{~mm}$.

At station M2 123 individuals were found, with a

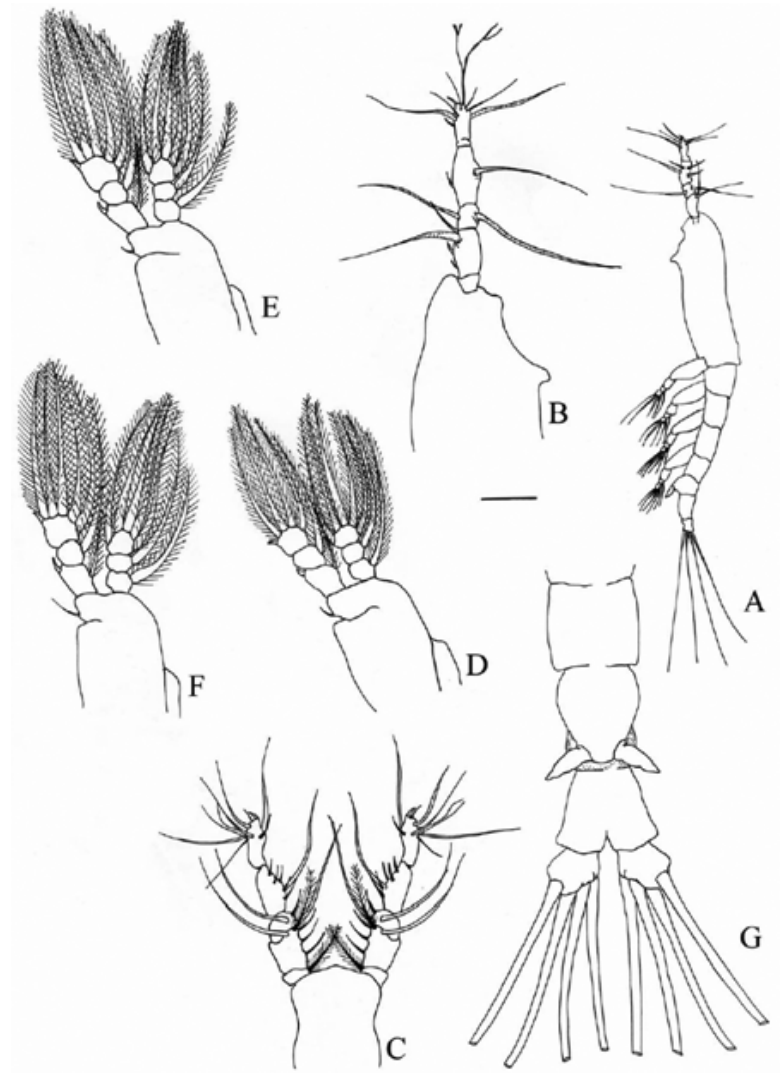

Fig. 3 - Cymbasoma longispinosum Bourne, 1890, m\#. (A) Male lateral view; (B) Lateral view of the head; (C) Dorsal view of the head; (D) Leg 1; (E) Leg 2; (F) Leg 4; (G) Ventral view of the urosome. Scale bar: $\mathrm{A}=0.6 \mathrm{~mm} ; \mathrm{B}$ and $\mathrm{C}=0.3 \mathrm{~mm} ; \mathrm{D}, \mathrm{E}, \mathrm{F}$ and $\mathrm{G}$ $=0.15 \mathrm{~mm}$.

mean density of 4.43 org. $\mathrm{m}^{-3}$, being 48 females and 75 males. Females presented minimum and maximum body lengths of $1.68 \mathrm{~mm}$ and 2.65 , respectively, with mean values of $2.10 \pm 0.03 \mathrm{~mm}$. Males body lengths ranged from $0.88 \mathrm{~mm}$ to $1.63 \mathrm{~mm}(1.31 \pm 0.02 \mathrm{~mm})$. Samples collected at stations M3 and M4 did not present any individuals of the Cymbasoma genera.

Of the sampling stations located in the Curuçá River (C1, C2, C3 and C4), only station C4 presented individuals of $C$. longispinosum. Eleven individuals were registered ( 7 males and 4 females), with a total density of 0.43 org. $\mathrm{m}^{-3}$. Male body lengths ranged from $1.00 \mathrm{~mm}$ to $1.53 \mathrm{~mm}(1.24 \mathrm{pm} 0.11 \mathrm{~mm})$, while female body lengths ranged from $1.80 \mathrm{~mm}$ to $2.48 \mathrm{~mm}$, with mean values of $2.14 \pm 0.10 \mathrm{~mm}$.

In November, C. longispinosum occurred only at 


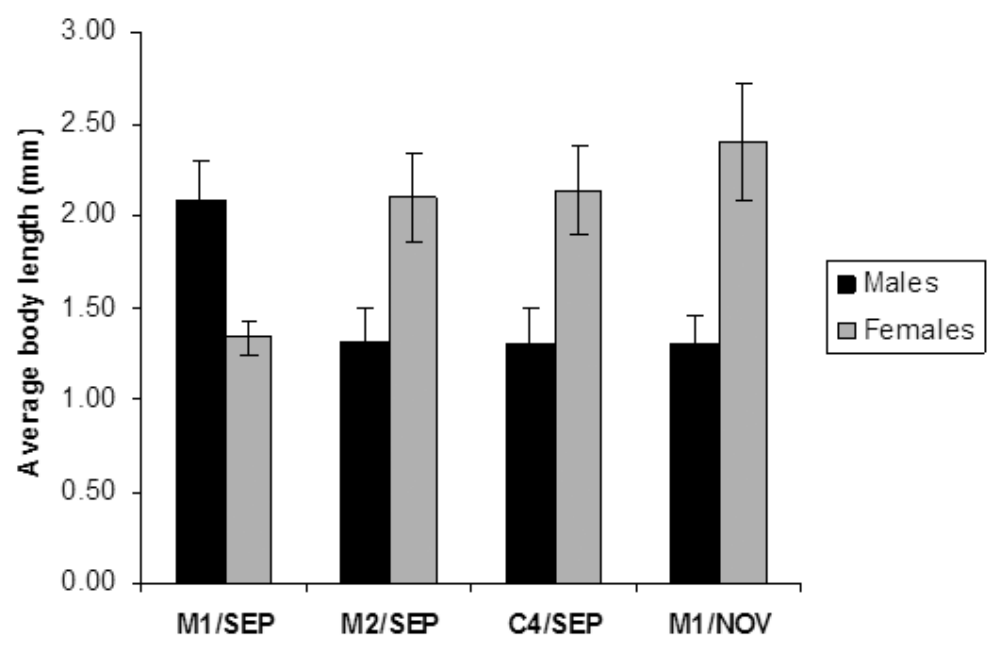

Fig. 4 - Average male and female body length variations (mean \pm SD) in the different months and sampling stations in the Curuçá River estuary (Curuçá County, Amazon Region).

station M1 (Muriá), with a total density of 0.29 org. $\mathrm{m}^{-3}$. Samples from this month were comprised of 8 individuals, being 5 females and 3 males. Male body lengths ranged from $1.13 \mathrm{~mm}$ to $1.50 \mathrm{~mm}(1.21 \pm 0.11 \mathrm{~mm})$, and females from $1.88 \mathrm{~mm}$ to $2.78 \mathrm{~mm}(2.40 \pm 0.16 \mathrm{~mm})$. Figure 4 shows the average body length variations for the different months and stations.

\section{DISCUSSION}

There is currently no available information on hydrological characteristics of the Curuçá estuary in the scientific literature. However, recorded salinity values for the Curuçá estuary were higher than those reported by Barletta-Bergan (1999) and Krumme and Liang (2004) in the Caeté estuary, and D.S. Santana, unpublished data, for the Marapanim estuary, both located in Northeast Pará (Amazon littoral). These estuaries, like others located in Northern Brazil, are submitted to a semidiurnal macrotide regimen and present high hydrodynamics characterized basically by the strong influence of rainfall and tidal current circulation (Barletta-Bergan 1999, Krumme and Liang 2004, Magalhães et al. 2006), which could explain the transport and, consequently, the wide distribution of $C$. longispinosum in the studied area.

The presence of $C$. longispinosum in samples obtained during September and November/2003 could probably be related to the reproductive period of this species in the studied estuary, which is directly related to the dry period in the region. The highest salinity values and the highest number of individuals observed in September/2003 corroborate with the previous assumption, since no $C$. longispinosum was found during the months comprising the rainy period (January to June). The presence of this copepod species in the inner portions of the Muriá creek could be related to the marine influence near the sampling stations, where the existence of other creeks could be verified connecting the Muriá creek to the Atlantic Ocean, as well as the creek's channel structure, which is wider than the Curuçá River. These results are in accordance with those reported by Dias (1996) and Duarte (1999), who recorded the presence of this species in high salinity ecosystems from the Sepetiba Bay (Rio de Janeiro) and the Espírito Santo Bay, both in Southeast Brazil.

According to the literature, $C$. longispinosum is a typical species in marine environments, occurring in tropical waters of the northeast Atlantic (Suárez-Morales 1994) and presenting an irregular distribution, which could be attributed to scant Monstrilloida in plankton collections worldwide and the reduced effort of studies about this copepod group (Isaac 1975).

Body length differences (Total length - cephalotorax and abdomen) among organisms from the Curuçá and other Brazilian ecosystems (Dias 1996, Duarte 1999) were observed. Females and males observed by 
Dias (1996) in the Sepetiba Bay (Rio de Janeiro, Brazil) presented body lengths ranging from 2.01 to $2.55 \mathrm{~mm}$, and 1.33 to $1.57 \mathrm{~mm}$, respectively. Duarte (1999), in the Espírito Santo Bay (Southeast Brazil) also reported female and male body lengths (1.98-2.54 mm, and 1.10 and $1.46 \mathrm{~mm}$, respectively) that were higher than the ones observed in this study. It was possible to note that individuals from Northern Brazil (Curuçá estuary) presented shorter body lengths than those recorded by Dias (1996) and Duarte (1999), except for males collected at station M1, which were much larger than those reported by the latter.

\section{ACKNOWLEDGMENTS}

This study was carried out as part of the Project Use and Appropriation of Coastal Zone Resources (Uso e Apropriação dos Recursos Costeiros - RECOS/CNPq/MCT) financed by the Conselho Nacional de Desenvolvimento Científico e Tecnológico (CNPq-Brazil), which was also responsible for scholarship support gave to the first author. Thanks to MSc. Marlon Aguiar Melo for his helpful assistance in the first drawing works. Finally, the authors Rauquírio Marinho da Costa (\#308953/2006-1) and Luci Cajueiro Carneiro Pereira (\#304392/2005-7) would like to thank the CNPq for their research grant.

\section{RESUMO}

O presente trabalho foi desenvolvido para verificar a ocorrência e distribuição de Cymbasoma longispinosum Bourne, 1890 em um estuário tropical amazônico da região norte do Brasil. As coletas foram realizadas bimestralmente de julho/2003 a julho/2004 em dois diferentes transectos (rios Muriá e Curuçá) situados ao longo do estuário do Curuçá (Pará, Norte do Brasil). Amostras foram coletadas durante marés de quadratura por intermédio de arrastos com redes de plâncton de $200 \mu \mathrm{m}$ de abertura de malha, através de um pequeno barco a motor (1 a 1,5 knots). Amostras adicionais de água subsuperficial foram coletadas para determinação dos parâmetros ambientais. Machos e fêmeas de $C$. longispinosum foram observados apenas durante os meses de setembro e novembro/2003. O maior número de organismos foi encontrado em setembro/2003, no transecto do rio Muriá. A presença de C. longispinosum nas amostras obtidas durante setembro e novembro/2003 poderia estar provavelmente relacionada ao período reprodutivo desta espécie no es- tuário estudado, o qual está diretamente relacionado ao período seco na região. Os mais elevados valores de salinidade, bem como os elevados números de indivíduos observados no mês de setembro/2003 confirmam a suposição anterior, visto que nenhum indivíduo de $C$. longispinosum foi registrado durante os meses que incluem o período chuvoso (janeiro a junho).

Palavras-chave: Região Amazônica, Monstrilloida, nova ocorrência, estuário tropical.

\section{REFERENCES}

Barletta-Bergan A. 1999. Structure and seasonal dynamics of larval and juvenile fish in the mangrove-fringed estuary of the Rio Caeté in North Brazil. Ph.D. Thesis, University of Bremen, Germany, $220 \mathrm{p}$.

DAVIS CC. 1984. Planktonic Copepoda (including Monstrilloida). In: Steidinger KA AND WALTER LM (Eds), Marine Plankton Life Cycle Strategies, Florida: CRC Press, Boca Raton, USA, p. 67-91.

DIAS CO. 1996. Monstrilloida (Copepoda) off the Brazilian coast. Hydrobiologia 324: 253-256.

Diretoria de Hidrografia E NAVEgaÇão (DHN). 2007. Tábuas das Marés. Fundeadouro de Salinópolis (Estado do Pará).<http://www.mar.mil.br/ dhn/tabuas $>$. Accessed Jan 2007.

DuARTE AK. 1999. Ocorrência de Monstrilloida (Copepoda) em águas costeiras do Sul do Brasil. Nauplius 7: 201-202.

EL-Robrini M. 1992. Evolution rapide des fonds d'une zone estuarine: Le secteur d'Itaqui-Baie São Marcos-Maranhão (Brésil). In: PRost MT (Ed), Évolution des littoraux de Guyane et de la Zone Caraïbe Méridionale pendant le Quaternaire Paris: ORSTOM, Paris, France, p. 159-175.

Grasshoff KM, Ehrhardt K AND KremLing K. 1983. Methods of seawater analysis, $2^{\text {nd }}$ ed., Weinheim, Deerfield Beach, Florida: Verlag Chemie, 419 p.

HuYs R AND Boxshall GA. 1991. Copepod Evolution, London: The Ray Society, 468 p.

IsAAC MJ. 1975. Copepoda. Sub-Order Monstrilloida. Fiches d'Identification du Zooplankton, Conseil International pour l'Exploration de la Mer 144-145: 1-10.

KRUMme U AND Liang T-H. 2004. Tidal-induced changes in a copepod-dominated zooplankton community in a macrotidal channel in Northern Brazil. Zoo Stud 43: 404-414.

MÁcola G And El-Robrini M. 2004. Ilha dos Guarás 
(Mariteua) - Município de Curuçá (NE do Pará): Aspectos Físicos, Meteorológicos e Oceanográficos. Relatório Final - Cartografia, Hidrografia e Digitalização - CHD \& Grupo de Estudos Marinhos e Costeiros - GEMC.

Magalhães A, Costa RM, Liang T-H, Pereira LCC AND RiBEIRO MJS. 2006. Spatial and temporal distribution in density and biomass of two Pseudodiaptomus species (Copepoda: Calanoida) in the Caeté River estuary (Amazon region - North of Brazil). Braz J Biol 66: $421-430$.

Mauchiline J. 1998. Advances in marine biology: The biology of Calanoid copepods, London: Academic Press, $\mathrm{UK}, 710 \mathrm{p}$.

Prost MT And El-Robrini M. 1997. Aplicações de Imagens de Radar para o Estudo do Meio Ambiente na Desembocadura do Rio Amazonas e do NE do Estado do Pará. Relatório Anual das Atividades Técnico-Científicas do Convênio CAPES - COFECUB.

Rose M. 1933. Faune de France: Copépodes pélagiques, Paris: Paul Lechevalier, 374 p.
SouZA Filho PWM AND El-Robrini M. 1997. A influência da variação do nível do mar na sedimentação da Planície Costeira Bragantina durante o Holoceno. In: Costa M And AngÉlicA R (Eds), Contribuições à Geologia da Amazônia, Belém: FINEP, Belém, PA, Brasil, p. 307-358.

STRICKLAND JDH AND PARSONS TR. 1972. A practical handbook of seawater analysis, $2^{\text {nd }}$ ed., Ottawa: Fisheries Research Board of Canada, 310 p.

SuÁrez-Morales E. 1994. Lista faunística comentada de los copépodos monstriloides (Crustacea, Copepoda) de la Baía de la Ascensión. Q Roo Sian Ka'an, Ser. Documentos 2: 11-17.

SuÁrez-Morales E AND GASCA R. 1998. Cymbasoma bowmani sp.nov., a new monstrilloid (Copepoda: Monstrilloida) from a Caribbean reef, with notes on species variation. J Mar Syst 15: 433-439.

Trégouboff G ANd Rose M. 1957. Manuel de planctonologie méditerranéenne, Paris: Centre Nacional de la Recherche Scientifique, 587 p. 